\title{
ISOLASI DAN IDENTIFIKASI SENYAWA MINYAK ATSIRI DAUN GAMAL (Gliricidia sepium [Jacq] Walp)
}

\author{
Ira Rahmiyani ${ }^{1}$, Taufik Rizki $\mathbf{R}^{\mathbf{1}}$, Nurlaili DH ${ }^{\mathbf{1}}$, Anna Yuliana ${ }^{\mathbf{1}}$ \\ ${ }^{1}$ Prodi Farmasi STIKes Bakti Tunas Husada, Jl.Cilolohan 36, Tasikmalaya, 46115 \\ E-mail:ira_rahmiyani@stikes-bth.ac.id
}

Riwayat artikel: Dikirim: 06/10/2020; Diterima: 28/10/2020, Diterbitkan: 31/12/2020

\begin{abstract}
Essential oils are one group of secondary metabolites that are mostly found in the tissues of plants. Gliricidia leaves can produce essential oils that are used as anti-bacterial and anti-scabies. The purpose of this study to determine the constituents of essential oil compounds in the leaves of Gliricidia. The method used distillation water vapor and analyze with gas chromatography mass spektroscopy (GC-MS). The results showed that the Gliricidia leaves contains 100 components of essential oil compounds and 3 major components of essential oil compounds as follows:2Pentadecanone, 6,10,14-trimethyl- (CAS) 6,10,14-Trimethyl-2-pentadecanone 20.07\%, 2Hexadecen-1-ol, 3,7,11,15-tetramethyl-, [R- [R *, R* - (E)]] - (CAS) Phytol 13.55\%, a 1.2Benzenedicarboxylic acid, bis (2-ethylhexyl) ester (CAS) - bis (2-ethylhexyl) phthalate 10,11\%.
\end{abstract}

Keywords: Gliricidia leaves, essential oil, gas chromatography mass spectroscopy (GC-MS).

\begin{abstract}
ABSTRAK
Minyak atsiri merupakan salah satu kelompok senyawa metabolit sekunder yang memiliki aroma khas dan mudah menguap. Daun gamal menghasilkan minyak atsiri yang dapat digunakan sebagai anti bakteri dan anti skabies. Tujuan penelitian ini untuk mengetahui komponen penyusun senyawa minyak atsiri dalam daun gamal. Metode yang digunakan untuk mengambil minyak atsiri dari daun gamal adalah destilasi uap air. Minyak atsiri yang dihasilkan dianalisis menggunakan Gas Chromatography Mass Spectroscopy (GC-MS). Hasil penelitian menunjukkan bahwa minyak atsiri daun gamal mengandung 100 komponen senyawa minyak atsiri dan 3 komponen senyawa utama minyak atsiri yaitu: 2-Pentadecanone, 6,10,14-trimethyl- (CAS) 6,10,14-Trimethyl-2-pentadecanone 20,07\%, 2-Hexadecen-1-ol, 3,7,11,15-tetramethyl-, [R-[R*,R*-(E)]]- (CAS) Phytol 13,55\%, 1,2Benzenedicarboxylic acid, bis(2-ethylhexyl) ester (CAS)-bis(2-ethylhexyl)phthalate 10,11\%.
\end{abstract}

Kata kunci: Daun gamal, Destilasi Uap Air , GC-MS, Minyak atsiri

\section{PENDAHULUAN}

Tanaman gamal (Gliricidia sepium [Jacq] Walp) merupakan tumbuhan di kawasan pantai pasifik Amerika Tengah dan mulai dibudidayakan dan bernaturalisasi di wilayah tropis Meksiko, Amerika Tengah, bagian Utara Amerika Selatan, sampai pada ketinggian 1500 meter Karibia dan kemudian Afrika Barat. Tanaman gamal mulai menyebar ke Filipina oleh orang
Spanyol pada awal tahun 1600an, dan ke Srilangka pada abad ke 18 kemudian ke Indonesia kira-kira tahun 1900an. Daun gamal di daerah kebanyakan digunakan sebagai pupuk kompos, pakan ternak, dan juga banyak digunakan sebagai tanaman pagar. Gamal juga digunakan sebagai anti skabies karena mengandung minyak atsiri (Natalia, dkk., 2009). 
Hasil Penelitian dari daun gamal. menunjukan bahwa aktivitas anti bakteri minyak atsiri terhadap bakteri Escherichia Coli dan Staphylococus aureus memberikan hasil yang positif dimana minyak atsiri daun gamal dapat memberikan efek anti bakteri yang baik terhadap E.coli (Farauqi, dkk., 2015). Komposisi minyak atsiri dalam daun gamal yang berasal dari Costarika tersusun dari methylbenzen, hexanal, (E)-3-hexen-1ol, (Z)-3-hexen-1-ol, (Chaverri dan jose, 2015). Ditinjau dari sumber alam minyak atsiri, senyawa mudah menguap ini dapat dijadikan sebagai sidik jari atau ciri khas dari suatu jenis tumbuhan karena setiap tumbuhan menghasilkan minyak atsiri dengan aroma berbeda atau spesifik. Terdapat beberapa jenis minyak atsiri yang memiliki aroma yang mirip tetapi tidak persis sama, dan sangat bergantung pada komponen kimia penyusun minyak tersebut (Agusta, 2000). Minyak atsiri tersusun atas golongan komplek sekitar 300 komponen senyawa di dalamnya. Senyawa yang memiliki persentase yang besar diantaranya adalah senyawa terpen yang terbentuk monoterpen. Komponen lain minyak atsiri di antaranya senyawa penilpropena (Agusta, 2000).

Mengingat belum adanya penelitian tentang identifikasi dan penentuan minyak atsiri daun gamal yang ada di Indonesia, maka perlu dilakukan isolasi dan identifikasi senyawa minyak atsiri pada daun gamal.

\section{BAHAN DAN METODE}

\subsection{Bahan dan Alat}

Bahan yang digunakan pada penelitian ini diantaranya daun gamal, NaSO4, kloralhidrat 70\%, pereaksi Mayer, pereaksi Dragendorff, serbuk $\mathrm{Mg}$ atau $\mathrm{Zn}$, alkohol, asam klorida, amil alkohol, $\mathrm{FeCl}_{3}$, gelatin $1 \%$, eter, pereaksi Anisaldehid$\mathrm{H}_{2} \mathrm{SO}_{4}$ atau Vanilin- $\mathrm{H}_{2} \mathrm{SO}_{4}$, pereaksi
Liebermann Burchard, $\mathrm{NaOH}$, metanol, etil asetat, n-heksan, $\mathrm{H}_{2} \mathrm{SO}_{4} 10 \%$, Aquadest.

Peralatan yang digunakan pada penelitian ini di antaranya; labu bersumbat, pengayak, gelas kimia, gelas ukur, tabung reaksi dan rak tabung, cawan uap, krus silikat, batang pengaduk, mikroskop, pipet volume, seperangkat alat destilasi dan Gas Cromatography-Mass Spectroscopy (GCMS) Varian Saturn 1000.

\subsection{Metode}

\subsubsection{Pengujian Parameter Mutu Simplisia}

Pengujian Parameter Mutu Simplisia dilakukan untuk mengetahui standar mutu simplisia yang meliputi pemeriksaan makroskopik mikroskopik, penapisan fitokimia, kadar air, susut pengeringan, kadar abu total, kadar abu tidak larut asam, kadar abu larut air, kadar sari larut etanol, kadar sari larut air. (Kemenkes RI,2011). Penapisan fitokimia dilakukan terhadap golongan senyawa alkaloid, saponin, kuinon, monoterpenoid/seskuiterpenoid, steroid, triterpenoid dan polifenol.

\subsubsection{Isolasi dan Identifikasi Komponen} Kimia Minyak Atsiri Daun Gamal

Daun gamal dilakukan pencucian menggunakan air mengalir, ditiriskan, kemudian dilakukan proses distilasi uap dan air selama 6 jam dengan variasi waktu pengambilan distilat untuk mendapatkan minyak atsiri dari dalam tanaman. Setiap minyak atsiri yang telah berhasil didapatkan kemudian ditambahkan $\mathrm{NaSO} 4$ anhidrat untuk menghilangkan kandungan air.

Identifikasi komponen fraksi minyak atsiri daun gamal dilakukan selama 1 jam dengan menggunakan instrumentasi GC-MS Varian Saturn 1000 di PT. Kimia Farma Unit Reserch And Development. Suhu injektor selama analisis berlangsung diprogram konstan pada suhu 230oC. Sementara temperatur interface adalah $250^{\circ} \mathrm{C}$ dan 
DOI : https://doi.org/10.24843/JFU.2020.v09.i03.p01

pISSN: 2301-7716; eISSN: 2622-4607

Jurnal Farmasi Udayana, Spesial Issue Desember 2020, 134-143

autosampling sebanyak $8 \mu$ l. Solvent cut time selama 3 menit dan Scan MS 50-450 $(\mathrm{M} / \mathrm{Z})$.

\section{HASIL}

\section{Hasil Parameter Mutu Simplisia}

Dari pemeriksaan makroskopik, daun gamal memiliki bentuk daun lonjong, tulang daun menyirip, batang daun pendek dan daging daun tipis. Daun gamal juga mempunyai bau yang khas dan serbuk daun ini berwarna hijau.

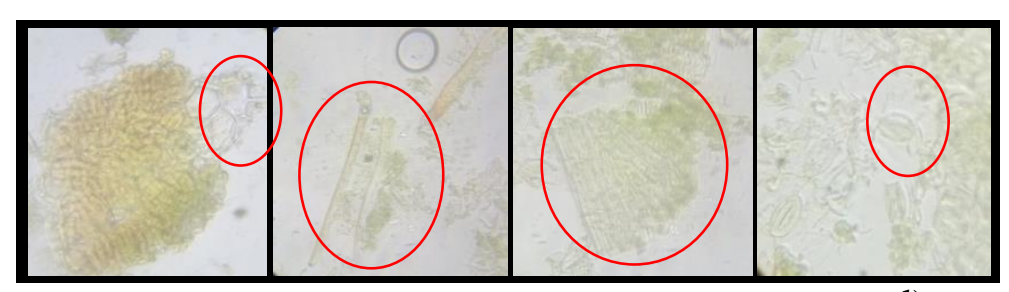

a)

b)

c)

d)

Gambar 1. Mikroskopik Serbuk Simplisia Daun Gamal (Gliricidia sepium) Pembesaran 400x a) epidermis atas, b)rambut penutup, c) jaringan berkas pembuluh, d) stomata tipe parasitik

Tabel 1. Hasil Penapisan Mutu Simplisia Daun Gamal

\begin{tabular}{lc}
\hline \multicolumn{1}{c}{ Jenis pengujian } & Persentase $\mathbf{( \% )}$ \\
\hline Kadar sari larut etanol & 50,11 \\
Kadar sari larut air & 30,23 \\
\hline Kadar air & 5,33 \\
Susut pengeringan & 8,76 \\
Kadar abu total & 8,43 \\
Kadar abu larut air & 6,27 \\
Kadar abu larut asam & 2,09 \\
\hline
\end{tabular}

Tabel 2. Hasil Penapisan Fitokimia Simplisia Daun Gamal

\begin{tabular}{lc}
\hline \multicolumn{1}{c}{ Golongan senyawa } & Hasil \\
\hline Alkaloid & + \\
Flavonoid & + \\
Polifenol & + \\
Tanin & - \\
Saponin & + \\
kuinon & - \\
monoterpen dan Seskuiterpen & + \\
Steroid dan Triterpen & + \\
\hline
\end{tabular}

Keterangan : (+) terdeteksi (-) tidak terdeteksi 
Rahmiyani dkk

DOI : https://doi.org/10.24843/JFU.2020.v09.i03.p01

pISSN: 2301-7716; eISSN: 2622-4607

Jurnal Farmasi Udayana, Spesial Issue Desember 2020, 134-143

Tabel 3. Hasil Pemeriksaan GC-MS Minyak Atsiri Daun Damal

\begin{tabular}{|c|c|c|}
\hline NAME & R.time & area\% \\
\hline 2- Propanoic acid, 3-(-2-hydroxiyphenyl)-(,E)- & 12.773 & 0.42 \\
\hline Ethanone,1-(4-hydroxylphenyl)-(CAS) p-hydroxyacetophenone & 12.919 & 0.58 \\
\hline Beta-citronellol & 15.786 & 1.30 \\
\hline $\begin{array}{l}\text { 2-cyclohexen-1-one, 5methyl-2-(1-methylethyl)-(CAS) p-menth- } \\
\text { 4-en-3-one }\end{array}$ & 16.534 & 0.15 \\
\hline Geraniol & 16.892 & 1.03 \\
\hline $\begin{array}{l}\text { 2-propanoic acid, 3-phenyl-,methyl ester (CAS) Cinamic acid } \\
\text { methyl ester }\end{array}$ & 22.226 & 0.26 \\
\hline Nerylacetate & 22.341 & 0.39 \\
\hline Retanol,acetat(CAS) vitamin a acetat & 22.542 & 0.24 \\
\hline (-)-.Beta.-elemane & 22.685 & 0.18 \\
\hline Hexadecane (CAS) n-hexsadecane & 23.032 & 0.13 \\
\hline Benzene, 1,2-dimethoxy-4-(2-propenyl)-(CAS) Methyleugenol & 23.206 & 7.40 \\
\hline & 23.383 & 0.13 \\
\hline $\begin{array}{l}\text { 9exo-methyl-anti(9,10)-tricyclo[4-2.1.1(2,5)]deca-3,7-diene- } \\
\text { 9endo,10endo-diol }\end{array}$ & 23.680 & 0.19 \\
\hline Cis-caryophyllene & 24.788 & 0.44 \\
\hline Alpha,-ionone & 24.109 & 0.39 \\
\hline Dihydro-.beta.-ionone & 24.561 & 0.11 \\
\hline 5,9-Undecadien-2-one, 6,10-dimethyl-(CAS) & 25153 & \\
\hline Dihydropseudoionone & 25.153 & 1.40 \\
\hline Eicosane (CAS) n-Eicosane & 25.579 & 1.14 \\
\hline Cyclododecane (CAS) & 26.116 & 0.38 \\
\hline 2,4,7-pteridenetriamine,6-methyl & 26.367 & 0.23 \\
\hline Beta-ionone & 26.484 & 3.61 \\
\hline Tetradecamethylcycloheptasiloxane & 26.745 & 0.36 \\
\hline Germacrene-d & 26.854 & 0.33 \\
\hline Cis-methyl isoeugenol & 26.953 & 0.61 \\
\hline Tetradecane, 1-chloro-(CAS)myristyl chloride & 27.087 & 0.37 \\
\hline Beta.-bisabolene & 27.417 & 0.14 \\
\hline Torreyol & 27.675 & 0.79 \\
\hline 3-Nonen-5-one & 27.749 & 1.36 \\
\hline $\begin{array}{l}\text { Cyclopentancarbonsaeure,2e,4z-dimethyl-3-methylen- } \\
\text {,methylester }\end{array}$ & 27.869 & 0.14 \\
\hline 9-Methyl-cis-decalin-1,8-dione & 27.998 & 2.13 \\
\hline [1,1'-Biphenyl]-3-qmine (CAS) m-Aminobiphenyl & 28.256 & 0.47 \\
\hline $\begin{array}{l}\text { (1rs,2rs)-2-methyl-2-(4'-methyl-3'- } \\
\text { pentenyl)cyclopropanecarbonyl chloride }\end{array}$ & 28.697 & 0.26 \\
\hline $\begin{array}{l}\text { 1h,3H-Thienol[3,4-c]thiophene, 4,6-dimrthyl- (CAS) 1,3-dihydro- } \\
\text { 4,6-dimethylthieno(3,4-C)thiophen }\end{array}$ & 28.783 & 0.10 \\
\hline Elemol & 28.993 & 1.36 \\
\hline $\begin{array}{l}\text { Butanic acid, 3,7-dimethyl-2,6-octadienyl ester,(E)- (CAS) } \\
\text { Geranyl butyrate }\end{array}$ & 29.444 & 0.58 \\
\hline $\begin{array}{l}\text { 9,12,15-Octadecatrienoic acid, methyl ester, (Z,Z,Z)- (CAS) } \\
\text { Methyllinolenate }\end{array}$ & 30.058 & 0.28 \\
\hline
\end{tabular}


DOI : https://doi.org/10.24843/JFU.2020.v09.i03.p01

pISSN: 2301-7716; eISSN: 2622-4607

Jurnal Farmasi Udayana, Spesial Issue Desember 2020, 134-143

Cholesta-8,24-dien-3-ol,4-methyl-, (3.beta,4.alpha.)-, (cas)

4.alpha.-methyl-.delta.-8,24-cholester

$30.162 \quad 0.17$

(-)-Caryophyllene oxide

$30.256 \quad 0.32$

Cyclohexane, 1,1-dimethyl-2,4-bis(1-methylethenyl)-, cis-(CAS)

Cyclohexane, 2e,4e,diisopropenyl-1

$30.387 \quad 0.24$

Cyclohexane, 1,1-dimethyl-2,4-bis(1-methylethenyl)-, cis-(CAS)

Cyclohexane, 2e,4e,diisopropenyl-1

$30.387 \quad 0.24$

Decane,3,8-dimethyl- (CAS) 3,8-Dimethyldecane

$30.970 \quad 0.12$

(-)-Caryophyllene oxide

$31.262 \quad 0.17$

Tetradecanal (cas) myristaldehyde

$31.405 \quad 0.24$

Widdrene

$32.003 \quad 0.32$

10-epi-.gamma.-eudesmol

$32.121 \quad 0.16$

.Delta.-cadinol

$32.519 \quad 0.68$

2-Undecene, 6-methyl-, (Z)- (CAS)

$32.583 \quad 0.37$

14,15,16-Trinor-8-.xi.-ladb-5-ene, 8,13-epoxy-,(-)- (CAS) 8,13-

OXIDO-14,15,16-trisnor-labd-5(6)-ene

$32.664 \quad 0.23$

Beta.-eudesmol

$32.798 \quad 0.26$

.Alpha.-cadinol

$32.976 \quad 0.82$

Patchouli alcohol

$33.044 \quad 0.70$

1-tetradecanol(CAS) Alfol 14

$33.871 \quad 0.61$

Decanenitrile (CAS) n-Decanonitrile

$34.419 \quad 0.58$

Methanamine, N,N-dimethyl- (CAS) Trimethylamine

$34.592 \quad 0.22$

Undecane, 3,5-dimethyl- (CAS)

$34.667 \quad 0.15$

Tridecanal (cas) tridecanaldehyde

$35.154 \quad 1.19$

Zerumbone (CAS) 2,6,10-Cycloundecatrien-1-one,2,6,9,9-

tetramethyl-, (E,E,E)- (CAS)

$35.780 \quad 0.50$

2-propanoic acid, 3-(4-methoxyphenyl)-,ethyl ester $\quad 36.554 \quad 0.22$

$37.059 \quad 0.14$

Iso-velleral

$37.865 \quad 0.26$

Hexadecanenitrile (CAS) Palmitonitrile $\quad 38.053 \quad 3.14$

$\begin{array}{lll}\text { Pentadecane (CAS) n-Pentadecane } & 38.193 & 0.10\end{array}$

Neophytadiene

$39.528 \quad 0.10$

2-Pentadecanone, 6,10,14-trimethyl- (CAS) 6,10,14-Trimethyl-2pentadecanone

$39.732 \quad 20.07$

5-eicosene, (e)- (cas)

$41.326 \quad 0.16$

2-Pentadecanone, 6,10,14-trimethyl- (CAS) 6,10,14-Trimethyl-2pentadecanone

$41.616 \quad 0.57$

(E,e)-farnesylacetone

$42.132 \quad 0.39$

3-ethenyl-3-methyl-4-pentenal

$42.219 \quad 0.29$

Cyclopentane, (4-octyldodecyl)- (CAS) 1-cyclopentyl-4-

)ctyldodecane

$42.292 \quad 0.10$

9-octadecenoic acid, 12-(acetyloxy)-,methyl ester, [R-(Z)]- (CAS)

Flexricin P-4

$42.416 \quad 0.16$

2-hexadecen-1-ol, 3,7,11,15-tetramethyl-,[R[R*,R*-(E)]]- (CAS) phyol

$43.109 \quad 0.30$

9-octadecynenitrile (CAS)

$43.775 \quad 0.13$

9,12,15-Octadecatrien-1-ol (CAS) octadeca-9,12,15-trien-1-ol

$43.974 \quad 0.50$

Heptadecanoic acid,ethyl ester (CAS) Ethyl n-heptadecanoate 
Rahmiyani dkk

DOI : https://doi.org/10.24843/JFU.2020.v09.i03.p01

pISSN: 2301-7716; eISSN: 2622-4607

Jurnal Farmasi Udayana, Spesial Issue Desember 2020, 134-143

Tetratetraconane (CAS) n-tetratetracontane

44.796

0.14

Sclareol

45.093

0.22

Octadecane, 1-chloro-(CAS) 1-Chlorooctadecane

$47.852 \quad 0.28$

2-Hexadecen-1-ol, 3,7,11,15-tetramethyl-, [R-[R*,R*-(E)]]-

(CAS) Phytol

$48.259 \quad 13.55$

2-methyl-5-undecylpyridine

$49.315 \quad 0.47$

Neophytadiene

$49.433 \quad 0.12$

Hentriaconate (CAS) untriaconate

$50.801 \quad 0.22$

Hentriaconate (CAS) untriaconate

$53.631 \quad 0.27$

2-methyl-5-undecylpyridine

$54.179 \quad 0.12$

Hentriaconate (CAS) untriaconate

$56.347 \quad 0.30$

Heptasiloxane, hexsadecamethyl- (CAS)

hexsadecamethylheptasiloxane

$58.087 \quad 0.33$

Hentriaconate (CAS) untriaconate

$58.965 \quad 0.31$

Hentriaconate (CAS) untriaconate

$61.479 \quad 0.27$

Heptacosane, 1-chloro-

61.980

0.36

Hentriaconate (CAS) untriaconate

63.919

0.35

Tetracosamethylcyclododecasiloxane

$64.314 \quad 1.12$

1,2-Benzenedicarboxylic acid, bis(2-ethylhexyl) ester (CAS)-

bis(2-ethylhexyl)phthalate

$64.995 \quad 10.11$

Heptasiloxane, hexsadecamethyl- (CAS)

hexsadecamethylheptasiloxane

$65.649 \quad 1.08$

Hentriaconate (CAS) untriaconate

$66.268 \quad 0.11$

Hentriaconate (CAS) untriaconate

$68.072 \quad 0.19$

Hentriaconate (CAS) untriaconate

$68.541 \quad 0.28$

Tetracosamethylcyclododecasiloxane

$69.140 \quad 1.52$

Heptasiloxane, hexsadecamethyl- (CAS)

hexsadecamethylheptasiloxane

$70.537 \quad 1.40$

Hentriaconate (CAS) untriaconate

$70.728 \quad 0.42$

Iron,monocarbonyl-(1,3-butadiene-1,4-dicarbonic acid,diethyl

ester) a,a- dipyridyl

$71.242 \quad 0.25$

Hahnfett

$72.066 \quad 0.21$

Tetracosamethylcyclododecasiloxane

$73.139 \quad 1.65$

Komponen penyusun utama minyak atsiri daun gamal tertinggi

Komponen penyusun utama minyak atsiri daun gamal

Tabel 4. Hasil Pemeriksaan Komponen Penyusun Utama Minyak Atsiri Daun Gamal

\begin{tabular}{clc}
\hline NO & \multicolumn{1}{c}{ Komponen senyawa } & Area \% \\
\hline $\mathbf{1}$ & $\begin{array}{l}\text { 2-Pentadecanone, 6,10,14-trimethyl- (CAS) } \\
\text { 6,10,14-Trimethyl-2-pentadecanone }\end{array}$ & 20,07 \\
$\mathbf{2}$ & $\begin{array}{l}\text { 2-Hexadecen-1-ol, 3,7,11,15-tetramethyl-, [R- } \\
\text { [R*, } \mathrm{R}^{*} \text {-(E)]]- (CAS) Phytol }\end{array}$ & 13,55 \\
$\mathbf{3}$ & $\begin{array}{l}\text { 1,2-Benzenedicarboxylic acid, bis(2- } \\
\text { ethylhexyl) ester (CAS)- bis(2- } \\
\text { ethylhexyl)phthalate }\end{array}$ & 10,11 \\
\hline
\end{tabular}




\section{Rahmiyani dkk}

DOI : https://doi.org/10.24843/JFU.2020.v09.i03.p01

pISSN: 2301-7716; eISSN: 2622-4607

Jurnal Farmasi Udayana, Spesial Issue Desember 2020, 134-143

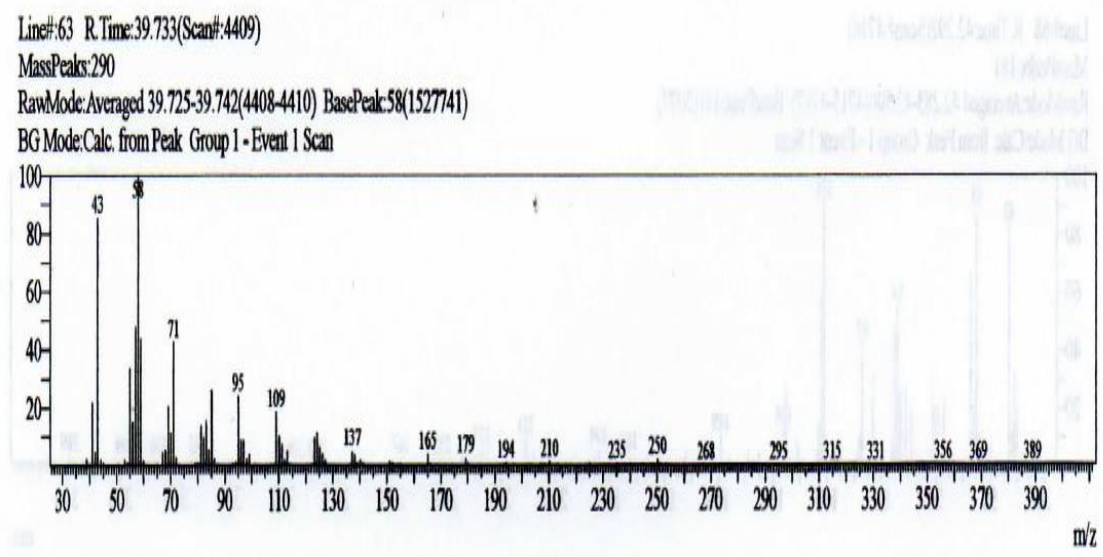

Gambar 2. Spektrum massa senyawa 2-Pentadecanone, 6,10,14-trimethyl-(CAS)6,10,14-Trimethyl-2 pentadecanon $58 \mathrm{~m} / \mathrm{z}$

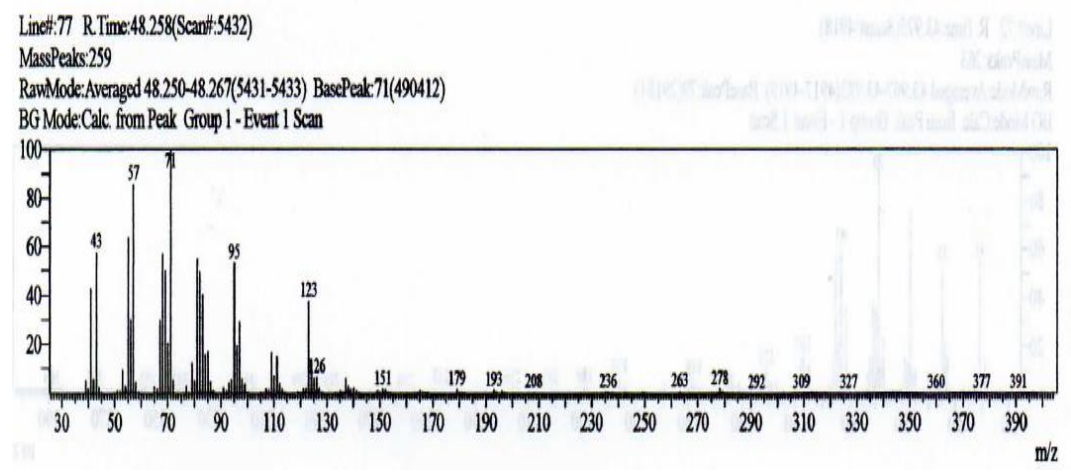

Gambar 3. Spektrum massa 2-Hexadecen-1-ol, 3,7,11,15-tetramethyl-, [R-[R*,R*-(E)]]-(CAS) Phytol 71 m/z

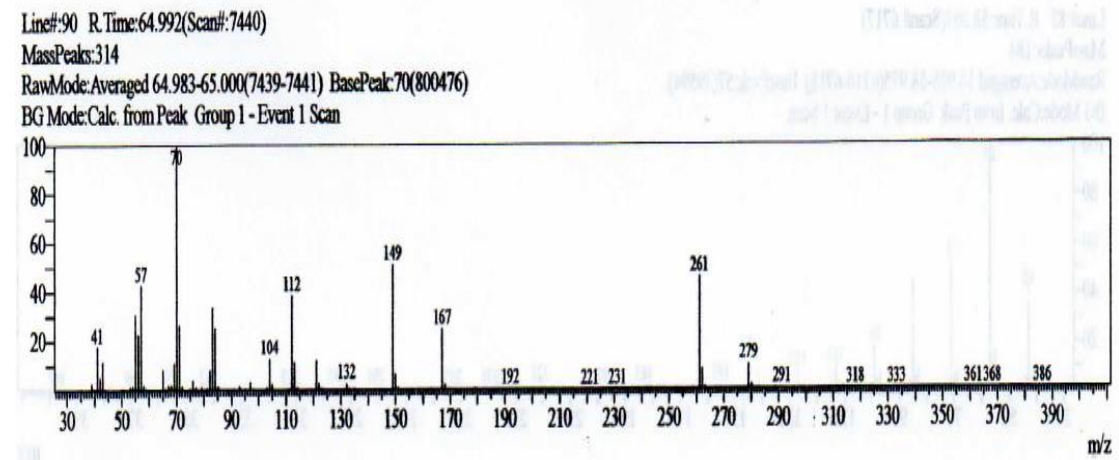

Gambar 4. Spektrum massa 1,2-Benzenedicarboxylic acid, bis(2-ethylhexyl) ester (CAS)-bis (2 ethylhexyl) phthalate $70 \mathrm{~m} / \mathrm{z}$ 
DOI : https://doi.org/10.24843/JFU.2020.v09.i03.p01

pISSN: 2301-7716; eISSN: 2622-4607

Jurnal Farmasi Udayana, Spesial Issue Desember 2020, 134-143

\section{PEMBAHASAN}

Destilasi uap air bertujuan untuk memisahkan minyak atsiri dari sampel dengan merubahnya menjadi uap yang dihasilkan oleh pemanasan. Dengan adanya kondensor, campuran uap tersebut akan didinginkan dan akan kembali menjadi cairan. (Agusta, 2000).

Proses destilasi daun gamal dilakukan beberapa hari dikarenakan rendemen yang di hasilkan dalam sekali penyulingan hanya sedikit $( \pm 0,1 \mathrm{~mL})$ sehingga sampel yang di butuhkan sangat banyak. Sampel yang digunakan untuk penyulingan adalah $130 \mathrm{~kg}$ daun segar, jika dikeringkan menghasilkan $20 \mathrm{~kg}$ simplisia. Menurut (Guenther, 1987) minyak atsiri dalam tanaman aromatik dikelilingi oleh kelenjar minyak, pembuluhpembuluh, kantung minyak atau rambut granular. Apabila bahan dibiarkan utuh, minyak atsiri hanya dapat diekstraksi apabila uap air berhasil melalui jaringan tanaman dan mendesaknya ke permukaan. Proses ekstraksi dalam keadaan tersebut hanya terjadi karena adanya peristiwa hidrodifusi, tetapi proses ini berlangsung sangat lambat bila bahan dalam keadaan utuh sehingga randemen yang dihasilkan rendah. Hal ini disebabkan karena kandungan minyak atsiri yang terdapat dalam daun gamal masih tetap tertahan di dalam jaringan dan sulit untuk terekstrak dengan baik. Hasil minyak atsiri yang di dapat dari daun gamal adalah $2 \mathrm{~mL}$, berwarna kuning dengan bau yang khas dan tekstur licin. Minyak atsiri yang diperoleh kemudian dilakukan identifikasi komponen senyawa menggunakan GC-MS.

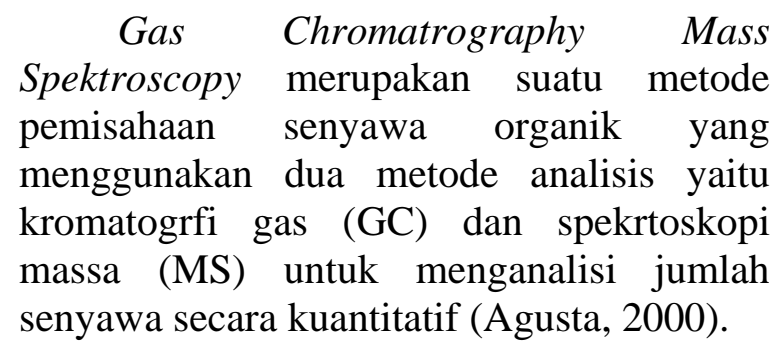

Hasil analisis dengan GC-MS,
menunjukkan bahwa daun gamal memiliki 100 senyawa minyak atsiri dan 18 diantaranya merupakan komponen utama penyusun minyak atsiri. Berdasarkan hasil penelitian yang dilakukan oleh Carlos Chaverrri dan Jose F. Ciccio, jumlah komponen senyawa minyak atsiri daun gamal yang berasal dari Costa Rica adalah 156 jenis dengan 12 komponen utama penyusunnya. Jumlah tersebut jauh lebih banyak dari komponen minyak atsiri daun gamal yang berasal dari Indonesia, namun jumlah komponen utama penyusunnya lebih kecil. Selain itu terdapat 3 komponen senyawa utama yang sama yaitu Geraniol, Germacrene-D, Eicosane dengan kadar yang berbeda. Salah satunya adalah kadar geraniol pada daun gamal asal Indonesia memiliki persentase yang lebih besar. Kadar germacrene-D lebih kecil, dan kadar Eicosane dapat terdeteksi. Perbedaan hasil yang diperoleh dimungkinkan terjadi karena perbedaan lingkungan tempat tumbuh mempengaruhi kandungan senyawa aktif dalam tumbuhan. Pertumbuhan tanaman dipengaruhi tinggi tempat, keadaan tanah dan iklim (Depkes RI, 1985) sehingga dapat berpengaruh terhadap jumlah kandungan senyawa pada suatu tanaman. Dari 18 komponen utama penyusun minyak atsiri daun gamal, terdapat tiga senyawa yang mempunyai persen area diatas $10 \%$ yang tersaji pada gambar 2,3 dan 4 .

Dari hasil spektrum diatas dapat diketahui senyawa 2-Pentadecanone, 6,10,14- trimethyl- (CAS) 6,10,14Trmethyl-2pentadecanon $\mathrm{m} / \mathrm{z} 268$; senyawa 2-Hexadecen-1-ol, 3,7,11,15-tetramethyl-, [R-[R*, R*-(E)]]- (CAS) Phytol m/z 71 dan senyawa 1,2-Benzenedicarboxylic acid, bis(2-ethylhexyl) ester (CAS)- bis(2ethylhexyl) phthalate $\mathrm{m} / \mathrm{z}$ 390. Senyawa 6,10,14-Trimethyl-2-pentadecanone pada konsentrasi tinggi dalam ekstrak etanol dan heksana daun bangle diketahui memiliki 
DOI : https://doi.org/10.24843/JFU.2020.v09.i03.p01

pISSN: 2301-7716; eISSN: 2622-4607

Jurnal Farmasi Udayana, Spesial Issue Desember 2020, 134-143

aktivitas antibakteri (Puspita sari, 2016). Senyawa 2-hexadecen- 1-ol, 3, 7, 11, 15tetramethyl-, [R-[R*,R*-(E)]]- (CAS) phytol merupakan acyclic diterpen alkohol yang berfungsi sebagai antimikroba, antiinflamasi dan antikanker. Senyawa 1,2Benzenedicarboxylic acid, bis (2-ethylhexyl) ester (CAS) bis(2-ethylhexyl) phtalate berkhasiat sebagai antimikroba, antioksidan dan antiperadangan dengan persen area cukup besar (Mastuti .R dan Handayani 2014).

Menurut Suprobo Dewi (2015) mekanisme kerja minyak atsiri dalam membunuh bakteri adalah dengan cara mengubah permeabilitas membran sel, menghilangkan ion-ion dalam sel, menghalangi proton-pump, dan menurunkan produksi adenosin trifosfat (ATP). Minyak atsiri bersifat lipofilik yang dapat melewati dinding bakteri karena dinding bakteri terdiri atas polisakarida, asam lemak, dan fosfolipid. Hal ini dapat mengakibatkan kerusakan dinding sel sehingga bakteri menjadi mati.

\section{KESIMPULAN}

Minyak atsiri daun gamal memiliki 100 komponen senyawa penyusun. Sebanyak 18 senyawa merupakan komponen utama. Tiga komponen senyawa penyusun utama yang tertinggi adalah 2-Pentadecanone,6,10,14trimethyl-(CAS) 6,10,14-Trimethyl-2pentadecanone; 2-Hexadecen-1-ol, 3,7, 11,15-tetramethyl-, [R-[R*, R*-(E)]](CAS)Phytol; 1,2-Benzenedicarboxylic acid, bis(2-ethylhexyl) ester(C AS)- bis(2ethylhexyl) phthalate. Ketiga senyawa tersebut diketahui merupakan senyawa yang berkhasiat sebagai antibakteri.

\section{UCAPAN TERIMAKASIH}

Ucapan terimakasih disampaikan kepada Prodi Farmasi STIKes Bakti Tunas Husada Tasikmalaya yang telah mendukung penelitian dan penulisan karya tulis ilmiah ini.

\section{DAFTAR PUSTAKA}

1. Agusta Andira. 2000. Minyak Atsri Tumbuhan Tropika Indonesia. Bandung:ITB ISBN 979-9299-14-4.

2. Ahmad Farjuqi. Endah R. Undang Ahmad D. 2015. Perbandingan Aktifitas Anti Bakteri Minyak Atsiri Dari Daun Kalikiria (Gliricidia Sepium (Jacq) Kunth Ex Walp.)Dan Daun Jeruk Bali (Citrus Maxima (Burm.)Merr) Terhadap Bakteri Escherichia Coli Dan Staphylococus aureus. Prosiding penelitian SPeSIA ISSN 2460-6472.

3. Carlos Chaverri and Jose.F.2015. Leaf and Flowers Essential Oil Compositions Of Gliricidia Spium (Fabacae) From Costa Rica. Amarican jourrnal of essensial end natural products: 2(3):1823.

4. Departemen Kesehatan Republik Indonesia. 1985. Cara Pembuatan Simplisia. Jakarta: Direktorat Jendral pengawasan Obat.

5. Fransworth, E.L. 1996. Biological and Phytochemical Screening of Plants.Journal of Pharmaceutical Sciences.Vol. 5.

6. Guenther, Ernest. 1987. Minyak Atsiri. Jilid 1. Diterjemahkan oleh S. Ketaren. Universitas Indonesia Press. Jakarta.

7. Kementrian Kesehatan Republik Indonesia.2011. Suplemen II Farmakope Herbal Indonesia.Edisi 1. Jakarta: Direktorat Jenderal Bina Kefarmasian dan Alat Kesehatan.

8. Natalia.Nista, dan Hindrawati. 2009. Keunggulan Gamal Sebagai Pakan Ternak. Palembang: BPTU Sembawa. 
DOI : https://doi.org/10.24843/JFU.2020.v09.i03.p01 pISSN: 2301-7716; eISSN: 2622-4607

Jurnal Farmasi Udayana, Spesial Issue Desember 2020, 134-143

9. Mastuti, Handayani. 2014. Senyawa Kimia Penyusun Ekstrak Ethyl asetat dari Daun Pisang Batu dan Ambon Hasil Distilasi air. Tangerang - Banten: Universitas Pelita Harapan

10. Puspita sari. 2016. Aktivitas Antibakteri Ekstrak Etanol Dan Heksana Daun Bangle (Zingiberis cassumunar Roxb) Terhadap Escericia Coli Dan Staphylococus Aureus. Yogyakarta: universitas Atmajaya Yogyakarta Fakultas Teknobiologi.

11. Suprobo Dewi. 2015. Aktivitas Antibakteri Minyak Atsiri Batang Sereh (Cymbopogen Citratus) Terhadap Propioninbacterium Acnes Secara In Vitro. Jember: Universitas Fakultas Kedokteran.

\footnotetext{
This work is licensed under a Creative Commons Attribution 4.0 International License
} 